IZA DP No. 7775

Couples' Labour Supply Responses to Job Loss:

Boom and Recession Compared

Mark Bryan

Simonetta Longhi

November 2013 


\title{
Couples' Labour Supply Responses to Job Loss: Boom and Recession Compared
}

\author{
Mark Bryan \\ ISER, University of Essex \\ Simonetta Longhi \\ ISER, University of Essex \\ and IZA
}

Discussion Paper No. 7775

November 2013

\author{
IZA \\ P.O. Box 7240 \\ 53072 Bonn \\ Germany \\ Phone: +49-228-3894-0 \\ Fax: +49-228-3894-180 \\ E-mail: iza@iza.org
}

\begin{abstract}
Any opinions expressed here are those of the author(s) and not those of IZA. Research published in this series may include views on policy, but the institute itself takes no institutional policy positions. The IZA research network is committed to the IZA Guiding Principles of Research Integrity.

The Institute for the Study of Labor (IZA) in Bonn is a local and virtual international research center and a place of communication between science, politics and business. IZA is an independent nonprofit organization supported by Deutsche Post Foundation. The center is associated with the University of Bonn and offers a stimulating research environment through its international network, workshops and conferences, data service, project support, research visits and doctoral program. IZA engages in (i) original and internationally competitive research in all fields of labor economics, (ii) development of policy concepts, and (iii) dissemination of research results and concepts to the interested public.
\end{abstract}

IZA Discussion Papers often represent preliminary work and are circulated to encourage discussion. Citation of such a paper should account for its provisional character. A revised version may be available directly from the author. 
IZA Discussion Paper No. 7775

November 2013

\section{ABSTRACT \\ Couples' Labour Supply Responses to Job Loss: Boom and Recession Compared ${ }^{*}$}

We examine how couples' labour supply behaviour in the UK responds to a job loss by one partner, using the Labour Force Survey to compare the period of growth of 1995-2007 to the Great Recession and its aftermath of 2008-11. In single earner couples during the recession, both men and women substantially increased their job search activity following a partner's job loss, while the increase in search during the boom was smaller (and non-existent for men). However, the increase in job search during recession did not appear to translate into more success in finding work for either men or women. Among dual earner couples, we find little evidence that individuals searched for alternative jobs or tried to increase their hours if their partner lost their job, except that women working part-time were more likely to start looking for another job. Both men and women were more likely to quit their job voluntarily if their partner lost their job, but the recession seems to have made people more cautious about voluntarily quitting their job. We find little evidence that people react in advance of job losses, suggesting that unemployment typically comes as a surprise.

JEL Classification: J22, J64

Keywords: $\quad$ added-worker effect, recession, employment, household labour supply

Corresponding author:

Simonetta Longhi

ISER

University of Essex

Wivenhoe Park

Colchester, CO4 3SQ

United Kingdom

E-mail: slonghi@essex.ac.uk

\footnotetext{
* This work is part of the project on "Understanding the Impact of Recession on Labour Market Behaviour in Britain", funded by the Economic and Social Research Council (ESRC), award no. RES062-23-3284. The support provided by ESRC and the University of Essex is gratefully acknowledged. This work was based on data from the Quarterly Labour Force Survey, 1992-2011, produced by the Office for National Statistics (ONS) and supplied by the Secure Data Service at the UK Data Archive. The data are Crown Copyright and reproduced with the permission of the controller of HMSO and Queen's Printer for Scotland. The use of the data in this work does not imply the endorsement of ONS or the Secure Data Service at the UK Data Archive in relation to the interpretation or analysis of the data. This work uses research datasets which may not exactly reproduce National Statistics aggregates.
} 
IZA Discussion Paper No. 7775

November 2013

\section{NON-TECHNICAL SUMMARY}

One advantage of living in a couple rather than alone is that economic risks can be shared. When a single person loses their job they have to fall back on personal savings, unemployment insurance or external support networks to maintain a minimum level of consumption. When a member of a couple loses their job, there is an additional margin of adjustment: the other partner may be able to take on more work to compensate. This paper investigates this 'household insurance' mechanism, also known as the added worker effect (AWE), with a focus on the role it played during the Great Recession and its aftermath (200811), as compared to the preceding period of economic growth (1995-2007). The analysis looks at the reactions of both women and men to their partners' job loss, in terms of looking for a (new) job, starting a job, increasing their hours, or holding onto their existing job. We also investigate whether couples react in advance of job losses or with a delay.

We find that in single earner couples during the recession, both men and women substantially increased their job search activity following a partner's job loss. This contrasts with the boom period, during which the increase in search was smaller (and non-existent for men). Thus couples appear to take a job loss 'in their stride' during periods of growth, but the more difficult conditions of recession lead the other partner to seek additional employment. However, the increase in job search during recession did not appear to translate into more success in finding work for either men or women (at least during a three month period). This suggests that couples cannot rely on insuring themselves against recessionary shocks by adjusting their household labour supply, because during a recession jobs are difficult to find for both partners.

Among dual earner couples, who are more cushioned against the loss of income from one earner, we find little evidence that individuals searched for alternative jobs or tried to increase their hours if their partner lost their job, except that women working part-time were more likely to start looking for another job. Moreover, both men and women were more likely to quit their job voluntarily if their partner lost their job, although the recession seems to have made people more cautious about voluntarily quits. We find little evidence that people react in advance of job losses, suggesting that unemployment typically comes as a surprise. 


\section{Introduction}

One advantage of living in a couple rather than alone is that economic risks can be shared. When a single person loses their job they have to fall back on personal savings, unemployment insurance or external support networks to maintain a minimum level of consumption. When a member of a couple loses their job, there is an additional margin of adjustment: the other partner can increase their labour supply. In this paper, we investigate this household insurance mechanism with a focus on the role it played during the Great Recession, as compared to the preceding period of economic growth. After rising from $69.0 \%$ in 1992 to $72.7 \%$ in 2007 just before the Great Recession, the UK employment rate fell back to $70.5 \%$ in 2011 (ONS 2013). This represented a major shock to households that affected both male and female earners (although the fall in men's employment was initially greater). ${ }^{1}$ As credit was less available during the recession and job losses less likely to be transitory, increased earnings by other household members may have made an important contribution to maintaining household consumption. Nevertheless, while previous studies have investigated how couples' labour supply responds to job loss by a partner, few have explicitly considered recessions and, to our knowledge, only two (one in the UK) have looked at the Great Recession.

We investigate for the UK how the job loss of one partner in a couple affects the job search, job finding and working hours of the other partner, comparing the period of the Great Recession and its aftermath (2008-11) to the preceding boom (from 1992 until 2007). Both theory and previous empirical papers have emphasised the need to examine the dynamics and timing of labour supply responses, and thus we use panel data from the UK Quarterly Labour Force Survey. In addition, we extend the existing literature in several ways. First, the previous Great Recession studies looked only at the first phase of the downturn (2008-9), which was dominated by men's job losses, while we have data up to 2011. Second, the literature has traditionally focussed on how women react to their male partners' job loss. Such a focus appears unwarranted now that the vast majority of working couples contain two earners, and thus we examine each partner's labour supply responses to the other's job loss. Third, unlike some previous work, we make an explicit distinction between job search and realised changes in labour supply (job finding, hours changes, and job retention), which may

\footnotetext{
${ }^{1}$ The employment rate of men fell by 2.5 percentage points (pp) between 2008 and 2009, compared with $0.9 \mathrm{pp}$ for women, but thereafter changes in employment were more evenly distributed. Both men and women experienced a $0.5 \mathrm{pp}$ drop in employment rates during 2009-10 and employment rates stabilised for both during 2010-11.
} 
be particularly important when there are demand-side constraints or frictions (likely to be more prevalent in a recession).

We find that in single earner couples during the recession, both men and women substantially increased their job search activity following a partner's job loss, while the increase in search during the boom was smaller (and non-existent for men). Thus couples appear to take a job loss 'in their stride' during periods of growth, but the more difficult conditions of recession lead the other partner to seek additional employment. However, the increase in job search during recession did not appear to translate into more success in finding work for either men or women, at least over a period of a quarter, consistent with their being frictions or constrained demand in the labour marker. Among dual earner couples, we find little evidence that individuals searched for alternative jobs or tried to increase their hours if their partner lost their job, except that women working part-time were more likely to start looking for another job. Moreover, both men and women were more likely to quit their job voluntarily if their partner lost their job, although the recession seems to have made people more cautious about voluntarily quits. We find little evidence that people react in advance of job losses, suggesting that unemployment typically comes as a surprise.

In the next section we discuss the background and previous literature on household responses to employment shocks. We present a more formal model in Section 3 that guides the empirical investigation in Sections 4-6. Section 7 summarises and discusses the results and their implication for understanding labour market behaviour.

\section{Background}

It has long been recognised that individuals and households can partially insure themselves against the income shocks from job loss by running down savings, borrowing or delaying purchase of durable goods (Attanasio et al 2005, Benito and Saleheen 2013). But the household, as opposed to the individual, benefits from an additional margin of adjustment: one member of the household may be able to take on additional work to compensate for another's job loss. This labour supply reaction is termed the Added Worker Effect (AWE) and was identified as long ago as the 1940s (Gong 2011).

Numerous studies have investigated the AWE since the advent of large-scale micro data in the early 1980s, focussing in particular on the response of women to their partner's job loss. While some studies conclude there is no AWE (Layard et al 1980, Spletzer 1997, Bingley and Walker 2001, Maloney 1991), others have found that women variously respond 
to a partner's job loss by looking for work (Lundberg 1985, Mattingley and Smith 2010), starting work (Lundberg 1985, Juhn and Potter 2007, Kohara 2010, Mattingley and Smith 2010) or increasing their work hours (Gong 2011, Harkness and Evans 2011). When positive, the typical size of estimated AWEs is a few percentage points, for example Gong (2011) found that the partners of men who lost their jobs were 3pp more likely to work full-time and $4 \mathrm{pp}$ more likely to increase work hours.

There are a number of reasons why AWE estimates may depend on economic context and thus vary across studies. Relatively modest effects may be expected if couples can rely on credit or other income sources, for example unemployment insurance (Cullen and Gruber 2000); if couples expect job losses to be temporary; or if the two partners' non-market time is complementary so a job loss raises the value of the other partner's non-market time (Maloney 1991). A job loss by one partner may also be a sign of weakness in the local labour market, such that it is more difficult for the other partner to find work or increase hours (Layard et al 1980). As discussed below, the balance of these factors generally changes during recessionary periods, and so we may expect to find that the AWE differs between booms and recessions.

In addition to these substantive factors, there are a number of methodological challenges involved in estimating the AWE, with corresponding differences of approach across studies. The first challenge is that unobserved factors that may affect both partners' labour market status and so obscure any causal relation from one partner's job loss to the other's labour supply. Analysis of employment in levels (e.g. Layard et al 1980) is particularly vulnerable to unobserved permanent differences between couples, for example if men and women with similar levels of unobserved skills or labour market attachment tend to marry, individuals who do not work will tend to be partnered with spouses who do not work either. For this reason, most recent studies, including the present analysis, use panel data to focus on employment transitions or allow for fixed effects (see Gong 2011). ${ }^{2}$

A related issue is that not all job losses are involuntary. A voluntary job quit may not prompt a response by the spouse (which would understate the true AWE) or the causality may be reversed if a husband is enabled to leave his job because his wife has increased her labour supply (potentially overstating the true AWE). While most studies focus on involuntary job losses, or moves from employment to unemployment, others look at any job loss, and indeed Mattingley and Smith (2010) argue that transitions to inactivity should also

\footnotetext{
${ }^{2}$ Spletzer (1997) argues that transitions are also affected by unobserved heterogeneity (men more susceptible to job loss tend to be married to women who also make more job transitions).
} 
be included because husband may be discouraged from looking for work or be forced retirees.

The timing of the job loss may be important (Gong 2011, Stephens 2002). A spouse may react immediately to her partner's job loss, or even before if there is advance warning. Alternatively it may take time for her to find a job if there are labour market frictions. Stephens (2002) finds small increases in wives' labour supply before a job loss and larger, persistent increases beginning with the job loss itself. There is some weak evidence that wives react further in advance of plant closings than layoffs, which it is argued are less publicised in advance. ${ }^{3}$

Perhaps surprisingly, few studies have compared recession and boom periods even though there are reasons to think that the AWE may be higher during a recession (Mattingley and Smith 2010). First, workers can expect to be unemployed for longer periods, so a job loss is less likely to be a transient shock. Second, credit is typically less available in recessions and particularly during the current downturn which was sparked by the credit crunch (Kamath et al 2011). Third, the Great Recession was not anticipated, so couples are more likely to have to resort to increased labour supply rather than savings to maintain their consumption. Fourth, the UK recession disproportionately hit men's jobs in its first phase (2008-9), thus the female partners of unemployed men may have been able to take up the slack. However, opposing these four factors, it is also possible that the lower overall level of labour demand in a recession reduces the likelihood of a partner finding work. Therefore on balance, the size of the AWE becomes an empirical question.

We are only aware of three previous studies that compare recessions and booms. Juhn and Potter (2007), using US data covering 1968-2005, found that the AWE was higher during periods when the economy was moving into recession (although the difference from other periods was not statistically significant). Mattingley and Smith (2010), comparing 2004-5 and 2008-9 in the US, found that the AWE was larger during 2008-9 (the recession); in particular women whose partners had lost their jobs were more likely to succeed in finding work (possibly because they were prepared to consider lower quality jobs). For the UK, Harkness and Evans (2011), using data from 2006-9, found that the women partnered with nonworking men were less likely to be in work, but that this negative association was reduced

\footnotetext{
${ }^{3}$ Within a basic lifecycle framework, job losses that were fully anticipated based on perceived 'normal' unemployment risk should not induce an AWE because couples should have already adjusted their savings and permanent levels of labour supply to accommodate these shocks. It is difficult to test this hypothesis owing to a lack of a data; Stephens (2002) attempts a test using estimated probability of job loss but the results are not conclusive.
} 
during 2008-9 (the recession). They found similar, but weaker relationships, using transitions data, concluding that job retention among women whose partners lost their jobs was higher in the recession than before. Compared to Harkness' and Evans' study, we use two additional years of data (covering the downturn until 2011), we examine men's reactions to their female partners' job loss, and we consider search behaviour - which we find to be an important dimension of the AWE. ${ }^{4}$

\section{Theoretical framework}

To provide a context for our empirical investigation we consider a lifecycle model of household labour supply (Stephens 2002). Forward-looking couples choose their labour supplies and household consumption to maximise (discounted) expected utility over the rest of their lives, given current expectations about future labour market prospects. Earnings not consumed can be saved, so the two partners can optimise their labour supply over the lifecycle (for example, working more when wages are higher) while maintaining a smooth consumption profile. The model implies a labour supply function of the following form:

$$
h_{p t}=f\left(\lambda_{t}, w_{1 t}, w_{2 t}, X_{p t}\right)
$$

where $h_{p t}$ is the number of hours worked by partner $p(=1,2$,$) at time t, \lambda_{t}$ is the marginal utility of wealth (reflecting the level of expected lifetime wealth), $w_{1 t}$ and $w_{2 t}$ are the wages of each partner respectively, and $X_{p t}$ are individual and household characteristics (such as number of children).

The key parameter in explaining the AWE is $\lambda_{t}$, the marginal utility of wealth. The effect of an unanticipated job loss is to lower the couple's expectations of future labour market prospects, thereby reducing their expected lifetime wealth and increasing $\lambda_{t}$. This in turn leads to an increase in the labour supply, $h_{p t}$, of the other partner (which is permanent because $\lambda_{t}$ is strongly persistent).

With some further simplifying assumptions (Stephens 2002), the labour supply of individual $i$ at time $t$ can be estimated as:

\footnotetext{
${ }^{4}$ We also restrict our attention to involuntary job losses, which are most relevant to our investigation of the AWE, whereas Harkness and Evans (2011) consider job losses in general. Voluntary and involuntary job losses may have different effects if, for example, a voluntary job loss is the result of a joint household decision about who should work.
} 


$$
h_{i t}=X_{i t}^{\prime} \beta_{1}+\beta_{2} w_{i t}+\sum_{k=-K}^{K} \beta_{3}^{k} P_{i t+k}+\mu_{t}+u_{i}+\varepsilon_{i t}
$$

In this specification, $\lambda_{t}$ is replaced by an unobserved individual effect $u_{i}$ (which includes the initial marginal utility of wealth $\lambda_{i 0}$ ), time effects $\mu_{t}$, and a set of dummy variables $P_{i t+k}$ indicating the partner's job loss in different periods (both before and after period $t$ ). Because $\lambda_{i 0}$ depends on a couple's initial assets and their expected wages in all periods, $u_{i}$ will almost certainly be correlated with the included regressors, so fixed-effect (FE) or differencing methods are needed.

The main implications of this framework are that unanticipated job losses (those that lower future expected earnings) lead to a permanent increase in the partner's labour supply. The increase may begin before the job loss if couples receive news of the job losses in advance. On the other hand, job losses that were anticipated (as being part of the inherent risk associated with an occupation) do not change expectations about lifetime wealth. Therefore they should not lead to changes in partner's labour supply, instead couples smooth consumption by borrowing or dis-saving during these temporary jobless periods.

However, the distinction between anticipated and unanticipated job loss is less clear if the model assumptions are relaxed to allow credit constraints: if couples cannot smooth consumption by borrowing (more likely during a recession), then even anticipated job losses will lead to partners increasing their labour supply (although the increase will only last until the unemployed partner regains a job). During the onset of a recession, we may expect a higher proportion of job losses to be unanticipated, the expected loss of earnings to be higher (because of longer expected unemployment duration), and credit constraints to be tighter. Thus the AWE may be higher in a recession.

Other factors may dampen reactions to job loss. First, partners' leisure time may be non-separable (time spent together is enjoyable or productive), so that a job loss increases the value of time spent at home for the other partner and so reduces the incentive to look for work. Second, job loss may be indicative of a weak local labour market (particularly during a recession) such that partners are not able to find work (this is termed the Discouraged Worker Effect, DWE). Finally, if there are labour market frictions individuals may not be able to move into work straightaway and thus the measured reaction may be muted or delayed. 
Since the net effect of all these factors is unclear a priori, we next turn to the data to estimate models based on equation (2), with outcomes that capture different dimensions of labour supply: changes in employment and hours of work and job search behaviour.

\section{Data and descriptive statistics}

\subsection{The UK Labour Force Survey}

To analyse couples' response to job loss over the business cycle we use the quarterly UK Labour Force Survey (LFS) for the period $1992 \mathrm{q} 2$ to $2011 \mathrm{q} 1 .^{5}$ The LFS is a survey of households which collects a large amount of individual and household characteristics, with focus on labour market variables such as education, employment status, job search activities, and job characteristics.

The LFS has a rotating panel structure in which individuals are interviewed for up to five successive quarters. This allows us to analyse quarter-on-quarter changes in the working situation of the members of the household. Our sample includes married or cohabiting couples who participated in the LFS for at least four consecutive quarters, and in which both partners are of working age but at least 23 years old (23-64 for men and 23-59 for women). We restrict the sample to people aged 23 and over to exclude individuals who may have a job but may still be completing their education; educational qualifications therefore become a time-invariant characteristic. As we wish to avoid potential complications arising from the labour supply of other household members, we also exclude from the sample those households in which other members - excluding the two partners - work. Finally, we exclude those households that are workless for the whole observation period, since they cannot be subject to employment loss. Roughly half of the couples in our sample have dependent children.

The survey asks questions on job search to both employed and unemployed respondents. Hence, besides analysing the probability that the respondent finds a job following a job loss of the partner, we can also identify whether the respondent is actively searching for a job. This is likely to be particularly important in periods of recession when it becomes harder to find a (new) job. Furthermore, since such questions are also asked to respondents who already have a job, we can analyse whether the impact of the partner's job

\footnotetext{
${ }^{5}$ Office for National Statistics. Social Survey Division and Northern Ireland Statistics and Research Agency. Central Survey Unit, Quarterly Labour Force Survey, 1992-2011: Secure Access [computer file]. 3rd Edition. Colchester, Essex: UK Data Archive [distributor], May 2013. SN: 6727.
} 
loss differs among employed and jobless respondents. We identify whether a person is looking for a job on the basis of their answers to three types of questions and classify as searching those who: (1) are looking for paid employment; (2) have looked for work in the last four weeks; and (3) mention at least one method of job search.

For respondents who already have a job we also analyse whether the partner's job loss is correlated with a change in working hours or with a different probability of quitting the current job voluntarily. We classify as voluntary quits those cases where the reason for leaving the previous job was: resigned; gave up job for health reasons; took early retirement; retired (at or after statutory retirement age); gave up job for family or personal reasons; and other reasons. Throughout the analysis our main explanatory variable is a dummy which has value one for all those respondents whose partner experienced an involuntary job loss (i.e. when the reason to leave the job was: dismissed; made redundant/took voluntary redundancy; or temporary job finished), and zero for those whose partner did not experience any change or quit their job voluntarily. Since the variable we use to identify the reason for the job loss is available only from the second quarter of 1995, our empirical models focus on this shorter time period, while the descriptive statistics use the longest period, starting in 1992, wherever possible.

\subsection{Descriptive Statistics}

Figure 1 shows the proportion of employed LFS respondents who lose their job by the following quarter. The left part of the Figure includes all types of job losses - voluntary and involuntary - and suggests that women are more likely than men to lose their job. The proportion of workers losing their job decreases from 1992 to 2007 and the difference between men and women reduces. From 2007, following the recent recession, the proportion of men losing their job shows a significant increase up to 2009, while the proportion of women losing their job keeps decreasing. The right part of Figure 1 focuses on involuntary job losses only and here we see a somewhat different pattern. Before the recession there are only minor differences between men and women and a flatter profile of job losses over time. However, with the onset of the recession the proportion of job losses increases sharply for both men and women, although the increase for men is much larger than the increase for women. Following these increases, however, job losses return to near previous levels so that the proportions in 2009 are similar or smaller than those in 1995. Our investigation of the AWE exploits both the spike in involuntary job losses that occurred post-2007 and the fact 
that households suffering job losses during this period were facing a much tougher economic environment than their counterparts in the preceding years.
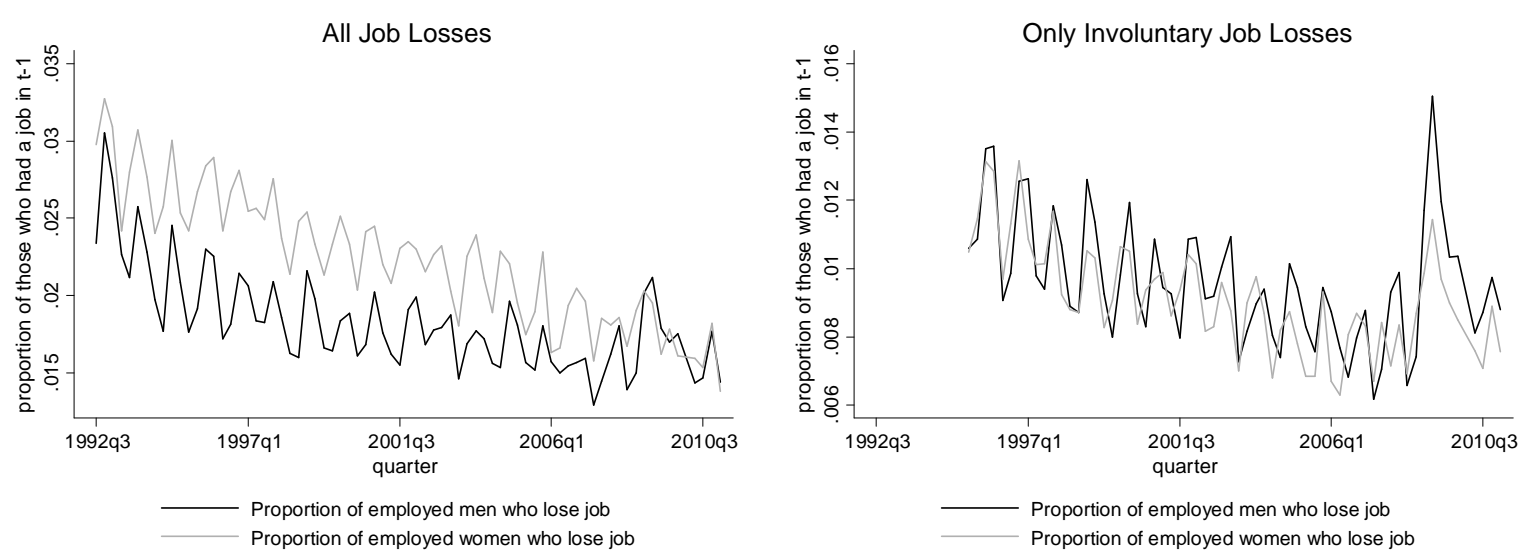

Figure 1: Job losses over the business cycle

Moving to the household level, Table 1 shows the proportions of different types of working households in our data. Among households without dependent children $59.8 \%$ are dual-earner households (i.e. both partners work). In $15.6 \%$ of cases the man is the breadwinner, while in $8.6 \%$ of cases the woman is the only one who works. Workless households (i.e. nobody works) are about $16.0 \%$ of the total. Among households with dependent children about $63.0 \%$ are dual-earner households, while in $25.4 \%$ of cases it is only the man who works. In about $3.8 \%$ of cases the woman is the breadwinner while $7.8 \%$ are workless households.

Table 1: Types of households (1992-2011)

\begin{tabular}{lcc}
\hline Breadwinners & $\begin{array}{c}\text { No } \\
\text { dependent children }\end{array}$ & $\begin{array}{c}\text { With } \\
\text { dependent children }\end{array}$ \\
\hline Both have a job & 0.598 & 0.630 \\
Man breadwinner & 0.156 & 0.254 \\
Woman breadwinner & 0.086 & 0.038 \\
Nobody works & 0.160 & 0.078 \\
\hline Total & 1.000 & 1.000 \\
Observations & 792,759 & 825,365 \\
\hline
\end{tabular}

Figure 2 shows how the proportions of the different types of households vary over time. The proportion of households in which both partners work increases over time, with a dip starting around 2008. The proportion of households in which only the man works, as well 
as the proportion of households in which nobody works seem to slightly decrease over time, although there is a very small increase in the proportion of workless households after 2008. The proportion of households in which only the woman works seems relatively stable, but as for workless households there is a small increase after the start of recession. Taken together, the changes after 2008 indicate that net employment losses among dual-earner households led to a small increase in the number of workless households and, especially, female-breadwinner households.

Although the figure does show some trends, the variations may appear rather small given the severity of the recession; one possible reason is that the unemployed represent only a relatively small proportion of the total active population (about 5\%-10\%). However, this overall picture of relative stability also reflects only the net effect of job losses and job gains and consequent movements between household types. It potentially obscures any operation of the AWE (if one partner loses a job but the other finds a job there is no net change to the number employed in the household), as well as changes in job loss and finding rates over the business cycle. In order to examine the dynamics of employment more directly, we next look at employment transitions for each household type.

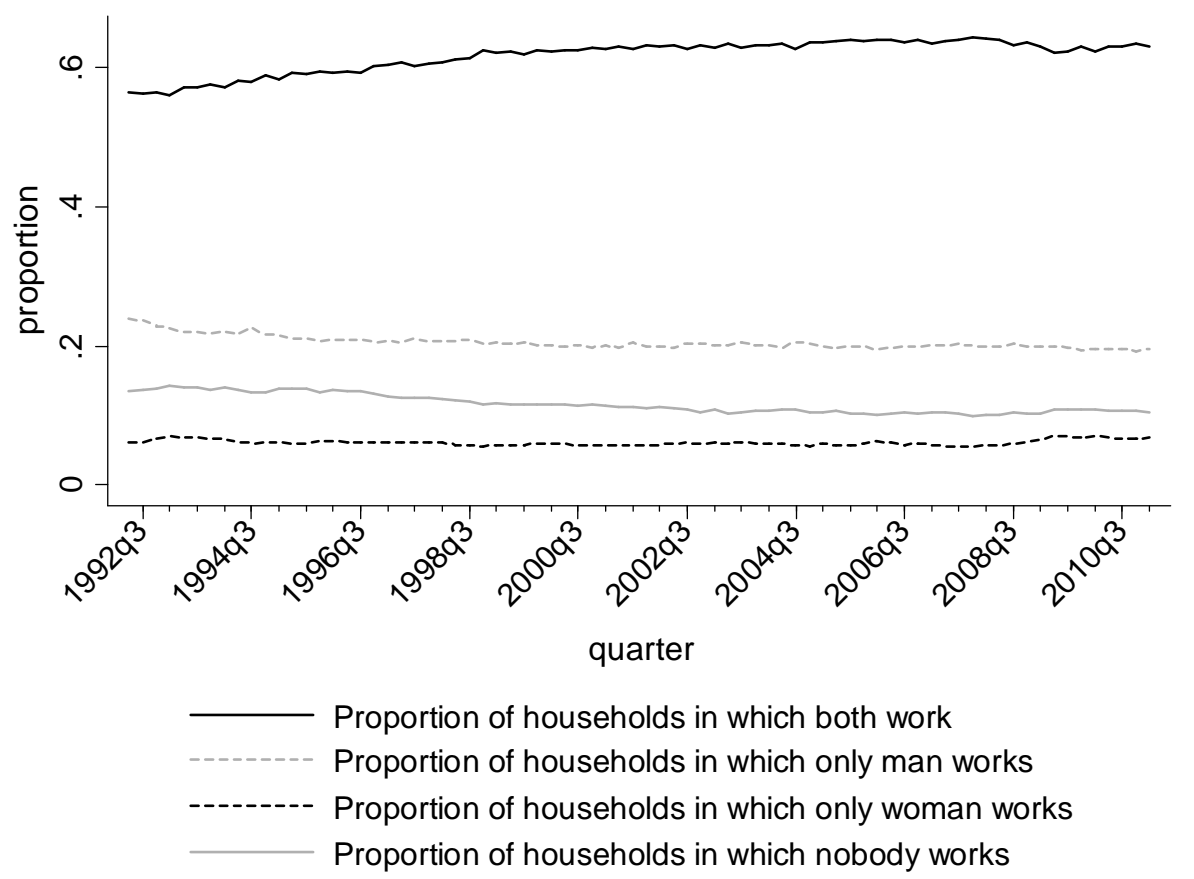

Figure 2: Household/couple types over the business cycle 
Table 2 shows the proportion of households moving across the different states between quarters. While the top panel focuses on the period of growth (1992-2007), the bottom panel focuses on the period of recession (2008-2011). The table suggests that the female partner seems less likely to find a job in recession than in growth: during the period of growth $8.2 \%$ of households move from a situation where the man is the breadwinner to a situation where both work, while moves in the same direction are $6.5 \%$ in the period of recession. There is a smaller difference in the probability that the male partner finds a job in recession versus growth: during the period of growth $11.3 \%$ of households moved from a situation where the woman is the breadwinner to a situation where both work, while the same proportion during the recession is $10.7 \%$. Despite this, the female partner also seems less likely to stop working in a period of recession than in a period of growth as the proportion of households moving from a situation where both work to a situation where the man is the breadwinner is $2.7 \%$ during the period of growth and $2.0 \%$ during the recession. For those households that are workless in $t-l$ it is the male partner who is more likely (than the female partner) to find a job, although the likelihood of finding a job is lower in periods of recession than in periods of growth.

Table 2: Quarter on quarter transition matrix

\begin{tabular}{lccccrr}
\hline $\begin{array}{l}\text { Breadwinners } t \rightarrow \\
\text { Breadwinners } t-1\end{array}$ & $\begin{array}{c}\text { Both } \\
\text { Work }\end{array}$ & $\begin{array}{c}\text { Man } \\
\text { Breadwinner }\end{array}$ & $\begin{array}{c}\text { Woman } \\
\text { Breadwinner }\end{array}$ & $\begin{array}{c}\text { Nobody } \\
\text { Works }\end{array}$ & Total & Observations \\
\hline Growth (1992-2007) & & & & & & \\
\hline Both have a job & 0.959 & 0.027 & 0.013 & 0.002 & 1.000 & 603,882 \\
Man breadwinner & 0.082 & 0.890 & 0.002 & 0.026 & 1.000 & 204,185 \\
Woman breadwinner & 0.113 & 0.006 & 0.839 & 0.042 & 1.000 & 58,709 \\
Nobody works & 0.006 & 0.039 & 0.016 & 0.938 & 1.000 & 115,027 \\
\hline Observations & 603,339 & 202,739 & 59,142 & 116,583 & & 981,803 \\
\hline & & & & & & \\
Recession (2008-2011) & & & & & & \\
\hline Both have a job & 0.965 & 0.020 & 0.013 & 0.001 & 1.000 & 94,452 \\
Man breadwinner & 0.065 & 0.909 & 0.002 & 0.025 & 1.000 & 29,460 \\
Woman breadwinner & 0.107 & 0.004 & 0.858 & 0.031 & 1.000 & 9,518 \\
Nobody works & 0.004 & 0.034 & 0.013 & 0.949 & 1.000 & 15,294 \\
\hline Observations & 94,146 & 29,228 & 9,690 & 15,660 & & 148,724 \\
\hline
\end{tabular}

Includes all households: with and without dependent children.

Overall then, and notwithstanding the temporary spike in male job losses seen in Figure 2, changes in household employment dynamics appear to be driven by lower job finding rates during the recession rather than by increased job losses. This may indicate that the AWE is unlikely to be larger in the recession to the extent it is more difficult for a non- 
working partner to enter employment (the DWE). Furthermore, Table 2 also reveals that the 'classic' AWE mechanism (in which one partner replaces the other in work) is relatively uncommon. Before the recession only $8 \%(=0.002 / 0.026)$ of male-breadwinners who lost their jobs were replaced by a female breadwinner, while $14 \%(=0.006 / 0.042)$ of femalebreadwinners who lost their jobs were replaced by a male breadwinner (with similar figures during the recession). However, the table represents only one possible dimension of couples' adjustment. Not shown in Table 2, but considered in the multivariate analysis, are changes in search activity, working hours and job retention.

\section{Method}

We analyse the impact that a partner's job loss has on labour market participation of the individual by looking at different types of reactions: job search, job finding, job retention, and changes in hours worked. The theoretical discussion in Section 3 emphasised the need to control for unobserved heterogeneity that may be correlated with the explanatory variables. Therefore our empirical specifications are based on equation (2) but are estimated as first differences (or as transitions) in order to remove the time invariant individual effects.

We start by estimating models for the probability of search, separately for those who have a job in $t-1$, and those who have no job in $t-1$ :

$$
S S_{i t}=X_{i t}^{\prime} \beta_{11}+\sum_{k=-1}^{1} \beta_{12}^{k} P_{i t+k}+\beta_{13} O_{i t}+\varepsilon_{1 i t}
$$

where the dependent variable $S S_{i t}$ is a dummy which identifies whether the individual starts searching between $t-1$ and $t$. The three dummies $P_{i t+k}$ are for changes in the employment situation of the partner. We test whether there is a lagged response to partner's job loss with a dummy for whether the partner lost the job involuntarily between $t$-2 and $t-1\left(P_{i t-1}\right)$; whether there is an immediate response with a dummy for whether the partner lost the job involuntarily between $t-1$ and $t\left(P_{i t}\right)$; and whether there is an anticipation effect by including a dummy for whether the partner lost the job involuntarily between $t$ and $t+1 \quad\left(P_{i t+1}\right)$. We analyse the impact of the recession by including interactions between these three dummies and a dummy identifying whether the change happens in a period of recession (i.e. if $t$ is between 2008 and 2010). The dummy variable $O_{i t}$ measures changes in the own employment 
situation and is defined differently according to which estimating sample is used. It is a dummy for whether the individual just lost her job between $t-1$ and $t$ when the model is estimated on those who had a job in $t$ - 1 , or a dummy for the individual who just found a job between $t-1$ and $t$ when the model is estimated on those who had no job in $t-1$. The reference is no change in the employment situation of the individual. $X_{i t}$ includes dummies for the characteristics of the household: one dummy for whether there are dependent children in the household, one for whether there are other dependants, and one for homeowners. We also include the square of age of the individual respondent and of the partner (the linear age term becomes a constant equal to one when first differences are taken), as well as a dummy for whether year $t$ was a year of recession or not. Time-invariant characteristics, such as education, are not included as regressors because they drop out in first differencing.

We then analyse the probability of finding a job between $t$ and $t-1$ :

$$
F_{i t}=X_{i t}^{\prime} \beta_{21}+\sum_{k=-1}^{1} \beta_{22}^{k} P_{i t+k}+\varepsilon_{2 i t}
$$

where $F_{i t}$ is a dummy which is one if the individual finds a job between $t-1$ and $t$, and zero otherwise. This specification estimates the AWE both for those who begin searching and find a job and also for those who find a job without a recorded spell of search in the previous period. We include here all types of jobs (paid jobs and starting own business) and only those who did not have a job in $t$-1 (both unemployed and inactive people). $P_{i t+k}$ and $X_{i t}$ are the same as in the previous models. The models are estimated for everybody, and then separately for people who were not searching in $t-1$.

Rather than start searching for a new or an additional job, those who already have a job may respond to their partner's job loss by changing the number of paid hours they work:

$$
\Delta H_{i t}=X_{i t}^{\prime} \beta_{31}+\sum_{k=-1}^{1} \beta_{32}^{k} P_{i t+k}+\varepsilon_{3 i t}
$$

where we only include people who have a job both at time $t-1$ and at time $t$ (although these may be different jobs). $H_{i t}$ is the change in the number of paid hours between $t-1$ and $t$ and $P_{i t+k}$ and $X_{i t}$ are the same as in the previous models. 
Finally we analyse job retention as people may be less likely to quit their job voluntarily as a response to partner's involuntary job loss. We estimate the following model:

$$
Q_{i t}=X_{i t}^{\prime} \beta_{41}+\sum_{k=-1}^{1} \beta_{42}^{k} P_{i t+k}+\varepsilon_{4 i t}
$$

where $Q_{i t}$ is one if the respondent quits the job voluntarily between $t-1$ and $t$ and zero otherwise; $P_{i t+k}$ and $X_{i t}$ are the same as in the previous models. Compared to prime age workers, those who are close to retirement age may react in a systematically different way to a job loss of their partners. Hence, the models in which the dependent variable is a voluntary quit only include respondents who are younger than 55 years of age.

All models are estimated using OLS, and we estimate all the models twice: once to analyse men's reactions to women's job loss and once to estimate women's reactions to men's job loss.

\section{Results}

Table 3 analyses men who have no job in $t-1$ and their reaction to their partner's job loss. Hence, this table focuses on single earner households in which the breadwinner at $t-1$ is the female partner. To our knowledge, ours is the first study to investigate the AWE in female, as opposed to male, breadwinner households. The first two columns show the impact that the woman's job loss has on the probability of starting searching for a job; while the first includes all men without a job, the second includes only men who were inactive at $t$ - 1 since by definition - unemployed people always search for a job. The last two columns of Table 3 analyse the impact of the woman's job loss to the probability that the workless man finds a job (accepts a job offer). The model is first estimated including everybody, and then including only men who were not searching for a job at $t-1$. Only a small proportion of men who find a job at time $t$ were classified as searching in $t-1$; most of them were not yet searching in the previous quarter, possibly indicating very short spells of search, not captured by our quarterly data.

The results suggest that the probability of starting searching for a job for men does not increase when the partner loses her job, even when we focus the analysis on inactive men only. This is consistent with the simple lifecycle model in which households anticipate 
occasional spells of unemployment and deal with them by means such as borrowing, dissaving or postponing durable purchases, rather than changing their labour supply behaviour. However, men's probability of starting to search actively for a job increases if the partner's job loss happens during a recession; the effect seems to be driven by inactive men, returning to the labour market, whose probability of starting a job search is $10 \mathrm{pp}$ higher if their partner has just lost her job The fact that a job loss prompts a larger response during the recession may reflect some of the factors discussed in Section 2: credit is tighter, restricting households' ability to borrow, and unemployment may have come as more of a surprise - but nevertheless is also expected to last longer. The search effect seems to be mostly contemporaneous, with possibly a lag: i.e. the search may start the same quarter of the job loss, or the following quarter. We find no evidence of any anticipation effect.

The last two columns of Table 3 suggest that on average men are more likely to find a job - or accept a job offer - if their partner loses her job; the response seems to be lagged one quarter, possibly reflecting frictions in the labour market. Those who are more likely to accept a job offer are those who were not classified as searching (and the results from the second column also indicate that they do not appear to report taking up job search before finding a job). Nevertheless, the probability of finding a job, on average, and as a response to the partner's job loss is lower during a recession. The additional recession effect is only significant at the $10 \%$ level, but suggests there may be a DWE that overrides the positive AWE. Thus, although men search more during the recession as a response to their partners' job loss, they are less likely to find a job. 
Table 3: Reaction to partner's job loss, men without a job at $t-1$

\begin{tabular}{|c|c|c|c|c|}
\hline \multirow[t]{2}{*}{ Dependent variable: } & \multicolumn{2}{|c|}{$\begin{array}{c}\text { Probability to start } \\
\text { searching for a job } S S_{i t}\end{array}$} & \multicolumn{2}{|c|}{$\begin{array}{l}\text { Probability of } \\
\text { finding a job } F_{i t}\end{array}$} \\
\hline & All & Inactive only & All & Not searching at $t-1$ \\
\hline \multirow{2}{*}{ Partner job loss $t-1$} & -0.002 & 0.001 & 0.023 & $0.057 * *$ \\
\hline & $(0.010)$ & $(0.012)$ & $(0.020)$ & $(0.018)$ \\
\hline \multirow[t]{2}{*}{ Partner job loss $t$} & 0.007 & 0.004 & -0.017 & 0.019 \\
\hline & $(0.011)$ & $(0.014)$ & $(0.022)$ & $(0.020)$ \\
\hline \multirow{2}{*}{ Partner job loss $t+1$} & 0.021 & 0.021 & -0.014 & -0.001 \\
\hline & $(0.012)$ & $(0.015)$ & $(0.024)$ & $(0.021)$ \\
\hline Ego just found job & $\begin{array}{c}-0.012 * * * \\
(0.003)\end{array}$ & $\begin{array}{l}0.006 \\
(0.005)\end{array}$ & & \\
\hline \multirow[t]{2}{*}{$\Delta$ age square (own) } & $-0.009 * * *$ & $-0.012 * * *$ & $-0.024 * * *$ & $-0.011 * *$ \\
\hline & $(0.002)$ & $(0.003)$ & $(0.005)$ & $(0.004)$ \\
\hline \multirow[t]{2}{*}{$\Delta$ age square partner } & $-0.005^{*}$ & $-0.006^{*}$ & $-0.031 * * *$ & $-0.015 * * *$ \\
\hline & $(0.002)$ & $(0.003)$ & $(0.005)$ & $(0.004)$ \\
\hline \multirow[t]{2}{*}{$\Delta$ dependent children } & 0.010 & 0.018 & $0.104 * * *$ & $0.100 * * *$ \\
\hline & $(0.014)$ & $(0.020)$ & $(0.028)$ & $(0.029)$ \\
\hline \multirow[t]{2}{*}{$\Delta$ other dependants } & 0.004 & 0.005 & -0.036 & -0.054 \\
\hline & $(0.019)$ & $(0.024)$ & $(0.039)$ & $(0.035)$ \\
\hline \multirow[t]{2}{*}{$\Delta$ home owners } & -0.008 & -0.009 & 0.062 & 0.032 \\
\hline & $(0.025)$ & $(0.033)$ & $(0.051)$ & $(0.046)$ \\
\hline \multirow[t]{2}{*}{ Recession at time $t$} & -0.003 & -0.006 & $-0.014^{*}$ & 0.000 \\
\hline & $(0.003)$ & $(0.004)$ & $(0.007)$ & $(0.006)$ \\
\hline \multirow[t]{2}{*}{ Partner job loss $t-1 \mathrm{x}$ Recession } & 0.050 & $0.086^{*}$ & -0.059 & $-0.142 *$ \\
\hline & $(0.030)$ & $(0.040)$ & $(0.061)$ & $(0.059)$ \\
\hline \multirow{2}{*}{ Partner job loss $t \mathrm{x}$ Recession } & $0.068^{*}$ & $0.102 * *$ & -0.013 & -0.067 \\
\hline & $(0.031)$ & $(0.038)$ & $(0.062)$ & $(0.054)$ \\
\hline \multirow{2}{*}{ Partner job loss $t+1 \times$ Recession } & -0.022 & -0.049 & -0.006 & -0.006 \\
\hline & $(0.032)$ & $(0.040)$ & $(0.065)$ & $(0.056)$ \\
\hline \multirow[t]{2}{*}{ Intercept } & $0.037 * * *$ & $0.041 * * *$ & $0.165^{* * *}$ & $0.088 * * *$ \\
\hline & $(0.001)$ & $(0.002)$ & $(0.003)$ & $(0.003)$ \\
\hline Adjusted R2 & 0.001 & 0.002 & 0.003 & 0.002 \\
\hline Observations & 28,668 & 20,692 & 28,668 & 21,495 \\
\hline
\end{tabular}

Table 4 analyses men who have a job in $t-1$ and their reaction to their partner's job loss and therefore focuses on those that were dual earner households in $t$ - 1 . The first column shows the impact that a job loss of the partner has on the probability of starting to search for a new or an additional job; the second column shows the impact on a change in hours worked; while the third shows the impact on the probability of giving up the job voluntarily. 
Table 4: Reaction to partner's job loss, men with a job at $t-1$

\begin{tabular}{|c|c|c|c|}
\hline Dependent variable: & $\begin{array}{c}\text { Probability to start } \\
\text { searching for a job } \mathrm{SS}_{\mathrm{it}}\end{array}$ & $\begin{array}{l}\text { Change in hours } \\
\text { worked } \Delta \mathrm{H}_{\text {it }}\end{array}$ & $\begin{array}{c}\text { Voluntary quit } \\
\mathrm{Q}_{\mathrm{it}} \\
\end{array}$ \\
\hline Partner job loss $t$ - 1 & $\begin{array}{l}-0.006 \\
(0.004)\end{array}$ & $\begin{array}{l}-0.205 \\
(0.143)\end{array}$ & $\begin{array}{c}0.001 \\
(0.002)\end{array}$ \\
\hline Partner job loss $t$ & $\begin{array}{c}0.008 \\
(0.004)\end{array}$ & $\begin{array}{c}0.177 \\
(0.147)\end{array}$ & $\begin{array}{l}0.020 * * * \\
(0.002)\end{array}$ \\
\hline Partner job loss $t+1$ & $\begin{array}{c}0.007 \\
(0.004)\end{array}$ & $\begin{array}{l}-0.191 \\
(0.148)\end{array}$ & $\begin{array}{c}0.002 \\
(0.002)\end{array}$ \\
\hline Ego just lost job & $\begin{array}{c}0.309 * * * \\
(0.002)\end{array}$ & & \\
\hline$\Delta$ age square (own) & $\begin{array}{c}-0.005^{* * *} * \\
(0.001)\end{array}$ & $\begin{array}{l}-0.013 \\
(0.028)\end{array}$ & $\begin{array}{c}0.001 \\
(0.000)\end{array}$ \\
\hline$\Delta$ age square partner & $\begin{array}{c}-0.004 * * * \\
(0.001)\end{array}$ & $\begin{array}{c}0.018 \\
(0.029)\end{array}$ & $\begin{array}{c}0.000 \\
(0.000)\end{array}$ \\
\hline$\Delta$ dependent children & $\begin{array}{l}0.007^{*} \\
(0.003)\end{array}$ & $\begin{array}{c}0.196 \\
(0.119)\end{array}$ & $\begin{array}{c}0.001 \\
(0.002)\end{array}$ \\
\hline$\Delta$ other dependants & $\begin{array}{l}-0.003 \\
(0.007)\end{array}$ & $\begin{array}{l}0.635^{*} \\
(0.248)\end{array}$ & $\begin{array}{c}-0.012 * * \\
(0.004)\end{array}$ \\
\hline$\Delta$ home owners & $\begin{array}{c}0.009 \\
(0.008)\end{array}$ & $\begin{array}{l}-0.034 \\
(0.288)\end{array}$ & $\begin{array}{c}0.001 \\
(0.004)\end{array}$ \\
\hline Recession at time $t$ & $\begin{array}{c}-0.004 * * * \\
(0.001)\end{array}$ & $\begin{array}{c}0.026 \\
(0.032)\end{array}$ & $\begin{array}{c}0.000 \\
(0.001)\end{array}$ \\
\hline Partner job loss $t-1$ x Recession & $\begin{array}{c}0.010 \\
(0.011)\end{array}$ & $\begin{array}{c}0.369 \\
(0.388)\end{array}$ & $\begin{array}{l}-0.002 \\
(0.006)\end{array}$ \\
\hline Partner job loss $t$ x Recession & $\begin{array}{c}0.001 \\
(0.011)\end{array}$ & $\begin{array}{c}0.565 \\
(0.369)\end{array}$ & $\begin{array}{l}-0.008 \\
(0.006)\end{array}$ \\
\hline Partner job loss $t+1 \times$ Recession & $\begin{array}{l}0.021^{*} \\
(0.010)\end{array}$ & $\begin{array}{l}-0.319 \\
(0.374)\end{array}$ & $\begin{array}{c}0.003 \\
(0.006)\end{array}$ \\
\hline Intercept & $\begin{array}{c}0.027 * * * \\
(0.000)\end{array}$ & $\begin{array}{l}-0.167 * * * \\
(0.014)\end{array}$ & $\begin{array}{c}0.006 * * * \\
(0.000)\end{array}$ \\
\hline $\begin{array}{l}\text { Adjusted R2 } \\
\text { Observations }\end{array}$ & $\begin{array}{c}0.054 \\
309,773\end{array}$ & $\begin{array}{c}0.000 \\
255,249\end{array}$ & $\begin{array}{c}0.000 \\
252,430\end{array}$ \\
\hline
\end{tabular}

Although on-the-job search seems to be less likely (by $0.4 \mathrm{pp}$ ) during a period of recession, Table 4 suggests that men who have a job do not seem to react to a job loss of their partner either by starting to engage in on-the-job search, or by changing the number of hours worked. Only in periods of recession do men seem to increase the probability of on-the-job search, in anticipation of the partner's job loss. However, the effect (of $2.1 \mathrm{pp}$ ) is statistically significant only at $10 \%$. Moreover the last column of the table suggests that on average men's attachment to the labour market decreases, not increases, when their partner loses her job: men are 2.0pp more likely to voluntarily quit their job as a response to their partner's job loss. This 'reverse AWE' may appear surprising but it is consistent with the two partners' non-market time being complementary, i.e. partners enjoy spending time together or they are 
more productive in home production together than alone. Evidence about retirement behaviour and the intra-household effects of work hours reduction policies suggests that complementary leisure leads people to work less if their partners also work less (Blau et al 1998, Goux et al 2013). In our case, this effect is unlikely to be driven by early retirement since these two models only include men younger than $55 .^{6}$

Following the analysis for men, we now turn to look at women's response to their male partners' job loss in Tables 5 and 6. Similarly to Table 3 for men, Table 5 focuses on women who have no job in $t-1$; while similarly to Table 4 for men, Table 6 focuses on women who have a job in $t-1$.

In contrast to men, women who do not have a job in $t-1$ seem to increase their probability of starting to search for a job in response to a partner's job loss; such increase is even larger if the job loss happens in a time of recession (see Table 5). This increase in the probability of starting a job search is mostly driven by inactive women, as unemployed women would search anyway. A woman whose partner has just lost his job in the previous quarter is $1.9 \mathrm{pp}$ more likely to start looking for a job in the period of growth and 8.4pp $(=1.9+6.5)$ more likely in the recession. These figures compare to no effect for men during the boom but an effect of 10pp in the recession (Table 3). Thus, while men and women's search responses appear to differ during the boom, they are much more similar (and large) during the recession. One difference in the recession is that the impact for women seems to be lagged, while it is contemporaneous for men. But again, for women, we find no evidence of anticipation effects.

Besides an increase in the probability of starting searching for a job, the partner's job loss does not seem to have any impact on the probability of women finding a job (see the last two columns of Table 5). ${ }^{7}$ The recession dummy suggests that it is harder for women to find a job during a recession; hence, despite a higher probability of searching for a job, the probability of getting a job for women does not seem to change in response to partner's job loss.

\footnotetext{
${ }^{6}$ The higher probability of quitting one's job in response to a partner's job loss applies equally to men with high (Level 4 or above) and low levels of education and therefore may not be driven by the income level of the household. Models estimated separately by men's education (not shown here but available on request) show regression coefficients that are slightly larger for men with low - rather than high - education. The results for women confirm that women with lower education are much more likely to quit their job in response to a partner's job loss - than women with high education.

${ }^{7}$ There is no impact on job finding, at least in the short term. Given that search occurs with a lag, if it also takes some time to find a job then we may not observe the new job within our time window. For example, the new job may not be recorded until two quarters after the job loss. Given our data structure we cannot observe job losses this far back.
} 
Table 5: Reaction to partner's job loss, women without a job at $t-1$

\begin{tabular}{|c|c|c|c|c|}
\hline \multirow[t]{2}{*}{ Dependent variable: } & \multicolumn{2}{|c|}{$\begin{array}{c}\text { Probability to start } \\
\text { searching for a job } \mathrm{SS}_{\mathrm{it}}\end{array}$} & \multicolumn{2}{|c|}{$\begin{array}{l}\text { Probability of } \\
\text { finding a job } F_{i t}\end{array}$} \\
\hline & All & Inactive only & All & Not Searching at $t-1$ \\
\hline \multirow[t]{2}{*}{ Partner job loss $t-1$} & $0.016^{*}$ & $0.019 * *$ & 0.005 & -0.003 \\
\hline & $(0.006)$ & $(0.007)$ & $(0.010)$ & $(0.009)$ \\
\hline \multirow[t]{2}{*}{ Partner job loss $t$} & $0.012 *$ & $0.015^{*}$ & -0.013 & -0.012 \\
\hline & $(0.006)$ & $(0.007)$ & $(0.010)$ & $(0.009)$ \\
\hline \multirow[t]{2}{*}{ Partner job loss $t+1$} & 0.006 & 0.005 & -0.008 & -0.014 \\
\hline & $(0.006)$ & $(0.007)$ & $(0.010)$ & $(0.009)$ \\
\hline \multirow[t]{2}{*}{ Ego just found job } & $-0.005^{*}$ & 0.003 & & \\
\hline & $(0.002)$ & $(0.003)$ & & \\
\hline \multirow[t]{2}{*}{$\Delta$ age square (own) } & $-0.004 * *$ & $-0.004 * *$ & $-0.011 * * *$ & $-0.008 * * *$ \\
\hline & $(0.001)$ & $(0.002)$ & $(0.002)$ & $(0.002)$ \\
\hline \multirow[t]{2}{*}{$\Delta$ age square partner } & $-0.007 * * *$ & $-0.008 * * *$ & $-0.010 * * *$ & $-0.007 * *$ \\
\hline & $(0.002)$ & $(0.002)$ & $(0.002)$ & $(0.002)$ \\
\hline \multirow[t]{2}{*}{$\Delta$ dependent children } & 0.006 & 0.007 & 0.024 & 0.023 \\
\hline & $(0.008)$ & $(0.009)$ & $(0.014)$ & $(0.012)$ \\
\hline \multirow[t]{2}{*}{$\Delta$ other dependants } & -0.024 & $-0.027 *$ & 0.024 & 0.015 \\
\hline & $(0.012)$ & $(0.014)$ & $(0.020)$ & $(0.018)$ \\
\hline \multirow[t]{2}{*}{$\Delta$ home owners } & -0.019 & -0.019 & 0.005 & -0.008 \\
\hline & $(0.014)$ & $(0.015)$ & $(0.022)$ & $(0.020)$ \\
\hline \multirow[t]{2}{*}{ Recession at time $t$} & -0.002 & -0.002 & $-0.013 * * *$ & $-0.011 * * *$ \\
\hline & $(0.002)$ & $(0.002)$ & $(0.003)$ & $(0.003)$ \\
\hline \multirow[t]{2}{*}{ Partner job loss $t-1$ x Recession } & $0.057 * *$ & $0.065 * * *$ & $-0.060 *$ & -0.037 \\
\hline & $(0.018)$ & $(0.020)$ & $(0.028)$ & $(0.027)$ \\
\hline \multirow[t]{2}{*}{ Partner job loss $t$ x Recession } & 0.009 & 0.010 & 0.024 & 0.016 \\
\hline & $(0.017)$ & $(0.019)$ & $(0.027)$ & $(0.025)$ \\
\hline \multirow[t]{2}{*}{ Partner job loss $t+1$ x Recession } & 0.002 & 0.008 & 0.010 & 0.026 \\
\hline & $(0.018)$ & $(0.020)$ & $(0.029)$ & $(0.026)$ \\
\hline \multirow[t]{2}{*}{ Intercept } & $0.033 * * *$ & $0.035 * * *$ & $0.090 * * *$ & $0.065 * * *$ \\
\hline & $(0.001)$ & $(0.001)$ & $(0.001)$ & $(0.001)$ \\
\hline Adjusted R2 & 0.001 & 0.001 & 0.001 & 0.001 \\
\hline Observations & 81,588 & 72,928 & 81,588 & 74,140 \\
\hline
\end{tabular}

The reaction of women who already had a job in $t-1$ is shown in Table 6. In contrast to men, women seem more likely than men to engage in on-the-job search as a response to a partner's job loss (we investigate below whether this concerns full or part-time workers). In this case the impact is contemporaneous (women whose partners have just lost their job are 2.0pp more likely to search) and there is no strong evidence of any impact of the recent recession. Consistent with what we found for men, the last column of Table 6 suggests that women seem more likely to quit as a response to their partner's job loss. In this case we find both a contemporaneous and a lagged effect, with the contemporaneous effect a little larger 
than for men (2.5pp compared to 2.0pp for men). However, there is some evidence that the recession reduces the rate of voluntary quits. Women are $0.6 \mathrm{pp}$ less likely to quit during recession and also on average less likely to quit as a lagged response to partner's job loss: the total lagged response in times of recession is $-1.5 p p$ (=1.9-3.4). Perhaps surprisingly, we also find that women seem to decrease the number of hours worked during a recession, in anticipation of the partner's job loss. This however, may be connected to our finding of a higher probability of voluntarily quitting one's job.

Table 6: Reaction to partner's job loss, women with a job at $t-1$

\begin{tabular}{|c|c|c|c|}
\hline Dependent variable: & $\begin{array}{c}\text { Probability to start } \\
\text { searching for a job } \mathrm{SS}_{\mathrm{it}}\end{array}$ & $\begin{array}{l}\text { Change in hours } \\
\text { worked } \Delta \mathrm{H}_{\mathrm{it}}\end{array}$ & $\begin{array}{c}\text { Voluntary quit } \\
\mathrm{Q}_{\mathrm{it}}\end{array}$ \\
\hline Partner job loss $t$ - 1 & $\begin{array}{l}0.000 \\
(0.005)\end{array}$ & $\begin{array}{l}-0.203 \\
(0.140)\end{array}$ & $\begin{array}{l}0.019 * * * \\
(0.004)\end{array}$ \\
\hline Partner job loss $t$ & $\begin{array}{c}0.020 * * * \\
(0.005)\end{array}$ & $\begin{array}{c}0.048 \\
(0.141)\end{array}$ & $\begin{array}{c}0.025 * * * \\
(0.004)\end{array}$ \\
\hline Partner job loss $t+1$ & $\begin{array}{c}0.002 \\
(0.005)\end{array}$ & $\begin{array}{l}-0.011 \\
(0.145)\end{array}$ & $\begin{array}{l}-0.001 \\
(0.004)\end{array}$ \\
\hline Ego just lost job & $\begin{array}{c}0.140 * * * \\
(0.002)\end{array}$ & & \\
\hline$\Delta$ age square (own) & $\begin{array}{c}-0.004 * * * \\
(0.001)\end{array}$ & $\begin{array}{c}0.018 \\
(0.025)\end{array}$ & $\begin{array}{l}-0.001 \\
(0.001)\end{array}$ \\
\hline$\Delta$ age square partner & $\begin{array}{c}-0.004 * * * \\
(0.001)\end{array}$ & $\begin{array}{l}-0.001 \\
(0.027)\end{array}$ & $\begin{array}{l}-0.001 \\
(0.001)\end{array}$ \\
\hline$\Delta$ dependent children & $\begin{array}{c}-0.011 * * \\
(0.003)\end{array}$ & $\begin{array}{l}-0.145 \\
(0.107)\end{array}$ & $\begin{array}{c}0.037 * * * \\
(0.003)\end{array}$ \\
\hline$\Delta$ other dependants & $\begin{array}{l}-0.004 \\
(0.008)\end{array}$ & $\begin{array}{l}-0.004 \\
(0.235)\end{array}$ & $\begin{array}{l}-0.006 \\
(0.007)\end{array}$ \\
\hline$\Delta$ home owners & $\begin{array}{l}0.021^{*} \\
(0.009)\end{array}$ & $\begin{array}{l}-0.237 \\
(0.284)\end{array}$ & $\begin{array}{l}-0.009 \\
(0.008)\end{array}$ \\
\hline Recession at time $t$ & $\begin{array}{l}-0.001 \\
(0.001)\end{array}$ & $\begin{array}{l}-0.024 \\
(0.029)\end{array}$ & $\begin{array}{c}-0.006 * * * \\
(0.001)\end{array}$ \\
\hline Partner job loss $t-1 \times$ Recession & $\begin{array}{l}-0.007 \\
(0.012)\end{array}$ & $\begin{array}{l}0.617 \\
(0.359)\end{array}$ & $\begin{array}{c}-0.034 * * \\
(0.012)\end{array}$ \\
\hline Partner job loss $t$ x Recession & $\begin{array}{l}-0.005 \\
(0.011)\end{array}$ & $\begin{array}{c}0.311 \\
(0.326)\end{array}$ & $\begin{array}{c}0.007 \\
(0.011)\end{array}$ \\
\hline Partner job loss $t+1 \times$ Recession & $\begin{array}{c}0.004 \\
(0.011)\end{array}$ & $\begin{array}{c}-0.844 * * \\
(0.323)\end{array}$ & $\begin{array}{l}-0.010 \\
(0.010)\end{array}$ \\
\hline Intercept & $\begin{array}{c}0.027 * * * \\
(0.000)\end{array}$ & $\begin{array}{c}-0.063^{* * * *} \\
(0.013)\end{array}$ & $\begin{array}{c}0.020 * * * \\
(0.000)\end{array}$ \\
\hline $\begin{array}{l}\text { Log likelihood/adjusted R2 } \\
\text { Observations }\end{array}$ & $\begin{array}{c}0.019 \\
256,111\end{array}$ & $\begin{array}{c}0.000 \\
215,687\end{array}$ & $\begin{array}{c}0.001 \\
221,076\end{array}$ \\
\hline
\end{tabular}

Finally, we could expect women's reaction to the partner's job loss to differ depending on the type of job she was working in at $t-1$ : we may see no added worker effect 
for women working full-time, while we may expect a bigger impact of partner's job loss on women working part-time (less than 30 hours per week). Table 7 replicates the models in Table 6, but separately for women who were working part- and full-time in $t-1$.

Table 7: Reaction to partner's job loss, women with a part- or full-time job at $t-1$

\begin{tabular}{|c|c|c|c|c|c|c|}
\hline \multirow[t]{2}{*}{ Dependent variable: } & \multicolumn{2}{|c|}{$\begin{array}{c}\text { Probability to start } \\
\text { searching for a job } \mathrm{SS}_{\mathrm{it}}\end{array}$} & \multicolumn{2}{|c|}{$\begin{array}{l}\text { Change in hours } \\
\text { worked } \Delta \mathrm{H}_{\mathrm{it}}\end{array}$} & \multicolumn{2}{|c|}{$\begin{array}{c}\text { Voluntary quit } \\
\mathrm{Q}_{\mathrm{it}}\end{array}$} \\
\hline & $\begin{array}{l}\text { Part-time } \\
\text { in } t-1\end{array}$ & $\begin{array}{l}\text { Full-time } \\
\text { in } t-1\end{array}$ & $\begin{array}{l}\text { Part-time } \\
\text { in } t-1\end{array}$ & $\begin{array}{l}\text { Full-time } \\
\text { in } t-1\end{array}$ & $\begin{array}{l}\text { Part-time } \\
\text { in } t-1\end{array}$ & $\begin{array}{l}\text { Full-time } \\
\text { in } t-1\end{array}$ \\
\hline Partner job loss $t-1$ & $\begin{array}{l}-0.010 \\
(0.007)\end{array}$ & $\begin{array}{c}0.008 \\
(0.006)\end{array}$ & $\begin{array}{c}-0.518 * * \\
(0.197)\end{array}$ & $\begin{array}{c}0.252 \\
(0.196)\end{array}$ & $\begin{array}{l}0.030 * * * \\
(0.007)\end{array}$ & $\begin{array}{l}0.012 * * \\
(0.004)\end{array}$ \\
\hline Partner job loss $t$ & $\begin{array}{c}0.030 * * * \\
(0.006)\end{array}$ & $\begin{array}{c}0.009 \\
(0.006)\end{array}$ & $\begin{array}{l}-0.250 \\
(0.202)\end{array}$ & $\begin{array}{l}0.423^{*} \\
(0.194)\end{array}$ & $\begin{array}{c}0.029 * * * \\
(0.007)\end{array}$ & $\begin{array}{c}0.023 * * * \\
(0.004)\end{array}$ \\
\hline Partner job loss $t+1$ & $\begin{array}{l}0.006 \\
(0.007)\end{array}$ & $\begin{array}{l}-0.002 \\
(0.006)\end{array}$ & $\begin{array}{l}-0.053 \\
(0.204)\end{array}$ & $\begin{array}{c}0.110 \\
(0.204)\end{array}$ & $\begin{array}{l}-0.001 \\
(0.008)\end{array}$ & $\begin{array}{c}0.001 \\
(0.005)\end{array}$ \\
\hline Ego just lost job & $\begin{array}{c}0.105^{* * *} \\
(0.002)\end{array}$ & $\begin{array}{c}0.206 * * * \\
(0.003)\end{array}$ & & & & \\
\hline$\Delta$ age square (own) & $\begin{array}{c}-0.004 * * \\
(0.001)\end{array}$ & $\begin{array}{c}-0.004 * * * \\
(0.001)\end{array}$ & $\begin{array}{c}0.001 \\
(0.038)\end{array}$ & $\begin{array}{c}0.000 \\
(0.034)\end{array}$ & $\begin{array}{l}-0.002 \\
(0.001)\end{array}$ & $\begin{array}{l}-0.000 \\
(0.001)\end{array}$ \\
\hline$\Delta$ age square partner & $\begin{array}{r}-0.003 * \\
(0.001)\end{array}$ & $\begin{array}{c}-0.006 * * * \\
(0.001)\end{array}$ & $\begin{array}{c}0.057 \\
(0.040)\end{array}$ & $\begin{array}{r}-0.089 * \\
(0.036)\end{array}$ & $\begin{array}{c}0.000 \\
(0.001)\end{array}$ & $\begin{array}{l}-0.002 * \\
(0.001)\end{array}$ \\
\hline$\Delta$ dependent children & $\begin{array}{l}-0.013 \\
(0.007)\end{array}$ & $\begin{array}{c}-0.014 * * * \\
(0.004)\end{array}$ & $\begin{array}{c}0.125 \\
(0.126)\end{array}$ & $\begin{array}{l}-0.122 \\
(0.217)\end{array}$ & $\begin{array}{l}0.046^{* * * *} \\
(0.008)\end{array}$ & $\begin{array}{c}0.039 * * * \\
(0.003)\end{array}$ \\
\hline$\Delta$ other dependants & $\begin{array}{c}0.021 \\
(0.011)\end{array}$ & $\begin{array}{l}-0.024 * \\
(0.011)\end{array}$ & $\begin{array}{c}0.457 \\
(0.325)\end{array}$ & $\begin{array}{l}-0.648 \\
(0.339)\end{array}$ & $\begin{array}{l}-0.021 \\
(0.013)\end{array}$ & $\begin{array}{c}0.006 \\
(0.007)\end{array}$ \\
\hline$\Delta$ home owners & $\begin{array}{c}0.035 * * \\
(0.012)\end{array}$ & $\begin{array}{c}0.007 \\
(0.013)\end{array}$ & $\begin{array}{l}-0.808 \\
(0.415)\end{array}$ & $\begin{array}{c}0.282 \\
(0.381)\end{array}$ & $\begin{array}{l}-0.012 \\
(0.014)\end{array}$ & $\begin{array}{l}-0.007 \\
(0.009)\end{array}$ \\
\hline Recession at time $t$ & $\begin{array}{l}-0.003 \\
(0.001)\end{array}$ & $\begin{array}{l}-0.000 \\
(0.001)\end{array}$ & $\begin{array}{c}0.038 \\
(0.041)\end{array}$ & $\begin{array}{l}-0.053 \\
(0.040)\end{array}$ & $\begin{array}{c}-0.008 * * * \\
(0.002)\end{array}$ & $\begin{array}{c}-0.004 * * * \\
(0.001)\end{array}$ \\
\hline Partner job loss $t-1 \mathrm{x}$ & & & & & & \\
\hline Recession & $\begin{array}{l}-0.004 \\
(0.020)\end{array}$ & $\begin{array}{l}-0.012 \\
(0.016)\end{array}$ & $\begin{array}{c}0.799 \\
(0.477)\end{array}$ & $\begin{array}{c}0.570 \\
(0.549)\end{array}$ & $\begin{array}{l}-0.050 * \\
(0.023)\end{array}$ & $\begin{array}{l}-0.022 \\
(0.012)\end{array}$ \\
\hline $\begin{array}{l}\text { Partner job loss } t \mathrm{x} \\
\text { Recession }\end{array}$ & $\begin{array}{c}0.003 \\
(0.016)\end{array}$ & $\begin{array}{c}0.008 \\
(0.015)\end{array}$ & $\begin{array}{l}-0.688 \\
(0.451)\end{array}$ & $\begin{array}{l}-0.986^{*} \\
(0.458)\end{array}$ & $\begin{array}{l}-0.014 \\
(0.019)\end{array}$ & $\begin{array}{l}-0.007 \\
(0.011)\end{array}$ \\
\hline Partner job loss $t+1 \times$ & & & & & & \\
\hline Recession & $\begin{array}{l}-0.003 \\
(0.016)\end{array}$ & $\begin{array}{l}-0.006 \\
(0.016)\end{array}$ & $\begin{array}{c}0.473 \\
(0.479)\end{array}$ & $\begin{array}{c}0.007 \\
(0.436)\end{array}$ & $\begin{array}{c}0.001 \\
(0.018)\end{array}$ & $\begin{array}{c}0.012 \\
(0.012)\end{array}$ \\
\hline Intercept & $\begin{array}{c}0.025^{* * *} * \\
(0.001)\end{array}$ & $\begin{array}{c}0.028 * * * \\
(0.001)\end{array}$ & $\begin{array}{c}-0.471 * * * \\
(0.019)\end{array}$ & $\begin{array}{c}0.386^{* * * *} \\
(0.018)\end{array}$ & $\begin{array}{c}0.028 * * * * \\
(0.001)\end{array}$ & $\begin{array}{c}0.013^{* * * *} \\
(0.000)\end{array}$ \\
\hline Log likelihood/adjusted $\mathrm{R}^{2}$ & 0.015 & 0.028 & 0.000 & 0.000 & 0.001 & 0.002 \\
\hline Observations & 123,418 & 132,661 & 112,575 & 103,097 & 102,947 & 118,102 \\
\hline
\end{tabular}

The results suggest that it is women working part-time who are more likely to start engaging in on-the-job search as a reaction to their partner's job loss. Women in part-time work seem more likely to decrease their working hours as a lagged response to the partner's 
job loss, while women in full-time job seem more likely to increase hours worked. Both parttime and full-time workers seem more likely to voluntarily quit their job as a response to their partner's job loss, with a larger response among part-time workers. Both show a contemporaneous and also a lagged one response.

As already seen in Table 5, on average the recession decreases the probability of quitting one's job; Table 6 indicates that this applies to both full-time and part-time workers. In addition, women working part-time also seem less likely to quit their job in response to the partner's job loss during the recession (but this differential recession effect is only significant at $10 \%)$.

In summary, we find that men without a job are likely to start searching for a job as a response to their partner's job loss, but only when this happens during a recession. For women we find an effect both in periods of growth and recession; the effect is however larger during a recession. Men are more likely to find a job - or accept a job offer - when their partner loses her job, but the effect seems to be lagged one quarter and there is some evidence that it is muted in recession.

Men who already have a job do not seem to react to their partner's job loss by engaging in on-the-job search or by changing their working hours. Women working parttime, instead, are more likely to start searching for a new or an additional job but we do not see any change in working hours. In response to their partner's job loss both men and women seem more likely to quit their job voluntarily, although this effect also seems to be lower during recession. Finally we find little evidence that couples react in advance of job losses.

\section{Discussion and conclusions}

We have examined how couples' labour supply behaviour in the UK responds to a job loss by one partner, comparing the period of growth of 1995-2007 to the Great Recession and its aftermath of 2008-11. Unlike previous studies, we have looked at the reactions of both women and men to their partners' job loss. We have investigated couples' reactions along the dimensions of search activity, job entry, changes in hours and job retention, and tested whether couples react in advance of job losses or with a delay.

Our first key finding is that job search activity increases significantly among single earner couples who lose their job during the recession. Irrespective of whether the breadwinner was male or female, the other (previously non-working) partner is substantially more likely (by some 10pp) to begin job search that if there was no job loss. This increase in 
search activity contrasts with the boom period, during which men are no more likely to begin a job search if their partner loses her job; while women are more likely to being searching but only by comparatively small amount (2pp). This result may indicate that while couples are able to take a job loss 'in their stride' during periods of growth (consistent with the standard lifecycle model), the more difficult conditions of recession (e.g. uncertainty over job prospects and tighter credit) lead the other partner to seek additional employment. As such, the lifecycle model appears less relevant during periods of recession.

Our second finding is that the increase in job search during recession does not appear to translate into more success in finding work for either men or women, at least in the short term (one quarter). During the boom, non-working men whose partners lose their jobs are more likely to find a job (but with a lag of up to one quarter), but there is still no effect for non-working women. These very modest effects for short-term job finding, despite evidence of greater search activity, are consistent with labour market frictions that slow down job finding as well as a labour market with constrained demand during the recession.

By contrast with single earner couples, we find little evidence that those in dual earner couples search for alternative jobs or try to increase their hours if their partner loses their job. Only women working part-time are more likely to start looking for another job (with no difference between boom and recession). On the contrary, it seems that a person's job loss may be a trigger for the other partner to stop work too. Both men and women are about 2-3pp more likely to quit their job voluntarily if their partner loses their job. This effect is consistent with the idea that couples' non-market time is complementary. However, it is important to note also that we find that not only has the recession reduced voluntary quits in general and but that it has also reduced the positive effect of a partner's job loss on voluntary quits. Thus it seems that people are more cautious about voluntarily quitting their jobs during recession.

Throughout the analysis we have distinguished between reactions to job loss that are delayed, contemporaneous and anticipated. While we find that reactions are often delayed or contemporaneous, we find little evidence that people act in advance of job losses, suggesting that unemployment typically comes as a surprise. While Gong (2011) similarly found no evidence of anticipatory effects and Stephens (2002) found relatively small effects, both studies looked at job losses a year ahead. We have supplied additional evidence that even job losses in the next quarter do not appear to be anticipated.

Our findings have shown how household behaviour differs between a boom and a recession. If a working household member loses their job during a boom, they presumably expect to find a new job relatively quickly and thus the AWE is small or non-existent 
(consistent with the lifecycle model). In a recession, a previously non-working partner begins to look for a job to maintain the earnings of the household, but it is precisely during this period that work is most difficult to find. Thus there is an AWE, but only in terms of search behaviour. This indicates that the insurance role played by the household is inhibited during recessionary periods for single earner households - thus external sources of insurance may be all the more important. Dual earner households may fare better: we see no evidence of any AWE among dual full-time couples during either boom or recession, suggesting that the second partner's continuing earnings provide something of a cushion, at least in the short term - but even these couples seem more reluctant to voluntarily sacrifice this second source of income in a recession. Overall, and consistent with those few previous studies which have compared booms and recessions, it appears that couples react to the job loss of a partner during recession by seeking to strengthen their labour market attachment.

\section{References}

Attanasio Orazio, Low Hamish, and Sánchez-Marcos Virginia (2005), "Female Labor Supply as Insurance Against Idiosyncratic Risk", Journal of the European Economic Association, 3(2/3): 755-764.

Benito, Andrew and Saleheen, Jumana (2013), "Labour Supply as a Buffer: Evidence from UK Households", Economica, 80: 1-23.

Bingley, Paul, and Walker, Ian (2001), "Household Unemployment and the Labour Supply of Married Women", Economica, 68(270): 157-185.

Blau, David M. (1998), "Labor Force Dynamics of Older Married Couples", Journal of Labor Economics, 16(3): 595-629.

Cullen, Julie Berry and Gruber, Jonathan (2000), "Does Unemployment Insurance Crowd out Spousal Labor Supply?", Journal of Labor Economics, 18(3): 546-572.

Gong, Xiadong (2011), "The Added Worker Effect for Married Women in Australia", Economic Record, 87(278): 414-426

Goux, Dominique, Maurin, Eric and Petrongolo, Barbara (2013), "Worktime Regulations and Spousal Labor Supply", American Economic Review, forthcoming.

Harkness, Susan, and Evans, Martin (2011), “The Employment Effects of Recession on Couples in the UK: Women's and Household Employment Prospects and Partners' Job Loss", Journal of Social Policy, 40(4): 675-693.

Juhn, Chinhui and Potter, Simon (2007), "Is There Still an Added Worker Effect?", Federal Reserve Bank of New York Staff Report no. 310.

Kamath Kishore, Reinold Kate, Nielsen Mette and Radia Amar (2011), "The Financial Position of British Households: Evidence from the 2011 NMG Consulting Survey", Bank of England Quarterly Bulletin, Q4, 305-318. 
Kohara, Miki (2010), “The Response of Japanese Wives' Labour Supply to Husbands' Job Loss", Journal of Population Economics, 23: 1133-1149.

Layard, R., Barton, M. and Zabalza, A. (1980), "Married Women's Participation and Hours," Economica, 47(185): 51-72.

Lundberg, Shelly (1985), “The Added Worker Effect”, Journal of Labor Economics, 3(1): 11-37.

Maloney, Tim (1991), "Unobserved Variables and the Elusive Added Worker Effect", Economica, 58(230): 173-187.

Mattingly, Marybeth J. and Smith, Kristin E. (2010), “Changes in Wives' Employment When Husbands Stop Working: A Recession-Prosperity Comparison", Family Relations 59: 343-357.

ONS (2013), Statistical Bulletin: Labour Market Statistics February 2013, Data Table A02, Office for National Statistics, February.

Spletzer, James R. (1997), "Reexamining the Added Worker Effect", Economic Inquiry, 35: 417-427

Stephens Jr., Melvin (2002), "Worker Displacement and the Added Worker Effect”, Journal of Labor Economics, 20(3): 504-537. 